\title{
Requirement of nitrogen, phosphorus and potassium fertilizers for wheat cultivation under irrigation by municipal wastewater
}

\author{
M.A. Mojid ${ }^{1 *}$, G.C.L. Wyseure' ${ }^{2}$ S.K. Biswas ${ }^{3}$ \\ ${ }^{1}$ Department of Irrigation and Water Management, Bangladesh Agricultural University, Mymensingh 2202, \\ Bangladesh; 'Department of Earth and Environmental Sciences, K.U. Leuven, Belgium; ${ }^{3}$ Bangladesh \\ Agricultural Research Institute, Gazipur. "Correspondingauthor:ma_mojid@yahoo.com
}

\begin{abstract}
This study quantified the optimum doses of nitrogen $(\mathrm{N})$, phosphorus $(\mathrm{P})$ and potassium (K) fertilizers for wheat (Triticum aestivum $L$. cv Shatabdi) cultivation under irrigation by municipal wastewater (here after called wastewater). Separate experiments were conducted with the three nutrients, applying each at five different doses and the other two at the recommended doses. An equal amount of irrigation by wastewater was provided to each experiment. The spike length, spikelets per spike, grain yield and harvest index of wheat increased with the increase in $\mathrm{N}$ dose up to $100 \mathrm{~kg} \mathrm{ha}^{-1}$, but decreased with further doses. Most of the growth and yield attributes improved significantly ( $p=0.05$ ) with the increase in P dose up to $20 \mathrm{~kg} \mathrm{ha}^{-1}$, beyond which the $\mathrm{P}$ exerted negative, but insignificant, effect on the crop attributes. The omission of $\mathrm{N}$ or P significantly reduced the yield attributes and yield of wheat, with the dominant effect of N. Either the omission or the higher than the recommended dose of K had no significant suppressing effect on the grain yield of wheat. The crop most effectively utilized the nutrients when supplied at the lower doses. The omission of $\mathrm{N}$ or P or K minimally reduced the 1000 -grain weight. The negative effects of the excess nutrient doses were the greatest for $\mathrm{N}$ and least for $\mathrm{K}$, implying that $\mathrm{N}$ was the most limiting and $\mathrm{K}$ was the least limiting factors for wheat production.
\end{abstract}

Keywords: wheat, irrigation, wastewater, optimum fertilizer dose. 


\section{Introduction}

The disposal of municipal wastewater is a major problem faced by the municipalities, particularly in the case of large metropolitan areas with limited space for land-based treatment and disposal. Consequently, more than $80 \%$ of the wastewater generated in the developing countries (e.g. Bangladesh) is discharged untreated into the environment, and about $50 \%$ of the population depends on polluted water sources for various uses, including irrigation (UNESCO, 2003). Various studies have shown that land application of municipal wastewater as water and/or nutrient source for crop production can stand for a sustainable alternative (Feigin et al., 1991; Pescod, 1992; Al Salem, 1996; Biswas et al., 1999; Yadav et al., 2002), although such practice is greatly affected by the problems of public acceptance (Pollice et al., 2004). Some treatments of wastewater prior to its use in irrigation are thought essential to protect human health and prevent contamination of soil and surface water bodies. The high energy costs, technology requirements and frequent maintenance problems of the treatment plants, however, render wastewater treatments ineffective for use in most developing countries. In practice, these countries use untreated/raw wastewater in agriculture for a number of reasons, such as higher than the potential yields for most crops and reduction in the requirements of inorganic fertilizers under irrigation by wastewater. For example, in Saudi Arabia, the irrigation by wastewater has increased crop production, and water and nitrogen use efficiencies, and served as a source of plant nutrients (Hussain and Saati, 1999).

The use of untreated municipal wastewater often poses a set of various problems. All crops need a specific amount of the major nutrients, such as nitrogen, phosphorus and potassium along with several micro nutrients for their normal growth and development. Once the nutrient doses exceed the optimum limit, the crop growth and yield are hindered. The excess nitrogen over the recommended dose for optimal yield stimulates the vegetative growth, delays ripening and maturity, and very often, causes yield loss of the crops. The wastewater-induced salinity, when becomes considerable, reduces the crop productivity due to general growth suppression at pre-early seedling stage, and nutritional imbalance and growth suppression due to the toxic ions (Kijne et al., 1998). Overapplication of the fertilizers is therefore considered a reason for the restriction of yield increase in the wastewater-irrigated crops. Due attention has not yet been given to develop a proper management strategy for irrigation by the municipal wastewater in Bangladesh, although a few peri-urban farmers have started irrigating their crops with this water. This study was therefore designed to determine the optimum dose of the three major nutrients: nitrogen, phosphorus and potassium for wheat cultivation under irrigation by municipal wastewater.

\section{Materials and methods}

\subsection{Experimental site}

The experiments of this study were conducted with wheat during November through March of 2009 2010 at the farm of the Bangladesh Agricultural University, Mymensingh $\left(24.75^{\circ} \mathrm{N}\right.$ latitude and $90.50^{\circ} \mathrm{E}$ longitude). The soil was silt loam with $0.48 \%$ organic matter, $6.8 \mathrm{pH}, 38.2 \%$ (v/v) field capacity, $18.37 \%$ $(\mathrm{v} / \mathrm{v})$ permanent wilting point, $1.33 \mathrm{~g} \mathrm{~cm}^{-3}$ bulk density and $0.62 \mathrm{dS} \mathrm{m}^{-1}$ electrical conductivity (EC). The climate of the region is sub-tropical humid with an average annual rainfall of $242 \mathrm{~cm}$ that is concentrated over May to September. The summer is hot and humid, and the winter (November - February) is mode- 
rate with occasional light rainfall. There was however no rainfall during the period of our field experiments, thus providing a controlled water management.

\subsection{Treatments and design}

Three experiments were designed with different dosecombinations of three major nutrients: $\mathrm{N}, \mathrm{P}$ and $\mathrm{K}$. The treatments of each experiment comprised four doses of one of the major nutrients; the other two major nutrients and, as micro nutrients, sulphur (S), zinc (Zn) and boron (B) were kept at their recommended doses. The variable doses of the nutrients included the smaller as well as the larger quantities than the recommended doses. The doses under test were 0,80 , 100,120 and $140 \mathrm{~kg} \mathrm{ha}^{-1}$ for $\mathrm{N} ; 0,10,20,30$ and 40 $\mathrm{kg} \mathrm{ha}^{-1}$ for $\mathrm{P}$ and $0,40,60,80$ and $100 \mathrm{~kg} \mathrm{ha}^{-1}$ for $\mathrm{K}$. The recommended doses of N, P, K, S, Zn and B for wheat cultivation in Bangladesh were 120, 30, 60, 15,5 and $1 \mathrm{~kg} \mathrm{ha}^{-1}$, respectively. These nutrients were applied in the form of triple super phosphate, muriate of potash, gypsum, zinc sulphate and borax fertilizers, respectively. The experiment was laid out in a randomized complete block design with three replications; the size of each plot 2 WAS $\mathrm{m} \times 2 \mathrm{~m}$.

\subsection{Cultural operations}

The entire doses of the fertilizers in the treatments of the experiments, except the urea, were applied to the prescribed plots during the final land preparation and incorporated into the soil. The urea was applied in two splits: two-thirds during the land preparation and the rest as top dress before the first irrigation at 20 days after sowing (DAS). The wheat seeds, @ $120 \mathrm{~kg}$ $\mathrm{ha}^{-1}$, were sown in 20-cm apart rows on 4 December 2009. There were weed infestation that was controlled effectively by uprooting. An incidence of cut worms was controlled by spraying the insecticide, Darsbarn.

The wastewater of Mymensingh municipality was collected in plastic barrels from the drainage canal of the sewerage system. The barrels were carried to the experimental field in a truck and the water was poured into a pit lined with polyethylene sheet. The water was mixed thoroughly to achieve a homogeneous mixture. Samples of wastewater were collected from the pit and analyzed by a DR/890 Colorimeter (Hach Co., USA) for their chemical properties. The (average) concentrations of $\mathrm{B}, \mathrm{Fe}, \mathrm{K}, \mathrm{NO}_{3}-\mathrm{N}, \mathrm{PO}_{4}-\mathrm{P}$, $\mathrm{Na}, \mathrm{Pb}, \mathrm{Cu}, \mathrm{Zn}$ and $\mathrm{Cd}$ in the wastewater were below their threshold values set by FAO (1992) for safe use in agriculture; only the Mn exceeded the limit. The concentration of $\mathrm{N}, \mathrm{P}$ and $\mathrm{K}$ in the wastewater was 17.5, 3.7 and $10.3 \mathrm{mg} \mathrm{L}^{-1}$, respectively. The details of the wastewater quality parameters of the Mymensingh sewage system were reported in Mojid et al. (2010). The irrigation was applied on the critical phenological growth stages of wheat: CRI (20 DAS), booting (50 - 55 DAS) and flowering (75 - 80 DAS). The soilwater content of the plots was measured before irrigation by a portable moisture meter, Trime FM (Eijelkamp, The Netherlands). The quantity of irrigation water was calculated by the difference between the soil-water content at field capacity and that prior to irrigation. The irrigation requirement was quantified for the effective root zone depth of $60 \mathrm{~cm}$. The soil in the field was characteristically homogeneous and so the soil-water contents in the plots were very consistent. Consequently, an average equal amount of water was applied to each plot in a particular irrigation. This provided an additional control in the treatments. The irrigation was applied manually in check basin. The quantity of irrigation water was $3.0,4.5$ and $5.5 \mathrm{~cm}$ in the first, second and third irrigation, respectively. 


\subsection{Data collection}

The leaf area and above-ground dry matter were collected four and five times, respectively during the growing season by clipping ten plants, selected randomly, at ground level from each plot. The leaf blades were separated from the sheath at the collar and their area was measured with a LI- 3100 (USA) leaf-area meter. The leaf area index (LAI) was calculated by the ratio of the measured leaf area of the ten plants to the ground area covered by these plants.

The mature wheat was harvested manually on 22 March 2010 from an area of one square meter at the middle of each plot that remained unaffected by periodical crop sampling. The total number of the fertile spikes was counted in the sampled crop for each plot. The plant height, spike length and number of spikelets per spike were recorded from randomly selected ten plants from each sample. The harvested crop of each plot including that of the ten sample plants was then threshed after sun drying and cleaned to separate the grains and straw. The grains were dried and weighed at $12 \%$ moisture content. One thousand clean and dry grains were counted from the seed stock of each plot and weighed. The biological yield, articulated by the sum of the grain and straw yields, was determined. The harvest index was calculated from the ratio of the grain yield to the biological yield. The analysis of variance of the growth and yield attributes, grain and biomass yields, and harvest index of wheat was done for the Randomized Complete Block Design. The R-package Agricolae (de Mendiburu, 2009) was used for the analysis. The significant level for comparison of the different treatments for the growth and yield attributes was set at $p=0.05$.

\subsection{Nutrient use efficiency}

The nutrient use efficiency (NUE) was calculated by using the difference in the nutrient of interest between the fertilized and control plots. The NUE was expressed as the physiological efficiency (PE), agronomic efficiency (AE) and crop recovery efficiency (RE). The $\mathrm{PE}$, defined by the grain yield per unit of nutrient uptake, entails the ability of a plant to transform a given amount of an acquired nutrient into the grain yield. The $\mathrm{AE}$ refers to the increase in crop yield per unit of an applied nutrient. The RE, on the other hand, refers to the increase in nutrient uptake by the plants per unit of an applied nutrient. These nutrient use efficiencies for different N, P and $\mathrm{K}$ treatments were calculated following Daradjat et al. (1991). As the example for $\mathrm{N}$

$$
\begin{aligned}
& \mathrm{PE}_{\mathrm{N}}=\frac{\text { grain yield }}{\mathrm{N} \text { uptake }}\left(\mathrm{kg} \mathrm{kg}^{-1}\right) \\
& \mathrm{AE}_{\mathrm{N}}=\frac{\text { grain yield at applied } \mathrm{N} \text { dose }- \text { grain yield at } \mathrm{N}_{\mathrm{o}}}{\text { applied } \mathrm{N} \text { dose }}\left(\mathrm{kg} \mathrm{kg}^{-1}\right) \\
& \mathrm{RE}_{\mathrm{N}}=\frac{\mathrm{N} \text { uptake at applied } \mathrm{N} \text { dose }-\mathrm{N} \text { uptake at } \mathrm{N}_{0}}{\text { applied } \mathrm{N} \text { dose }} \quad(\%)
\end{aligned}
$$

In the above expressions, the uptake of a nutrient means its uptake in the above-ground biomass and was expressed in kilogram per hectare; the applied dose of a nutrient means its rate of application and was also expressed in kilogram per hectare; and $\mathrm{N}_{0}, \mathrm{P}_{0}$ and $\mathrm{K}_{0}$ imply the omission of the respective nutrients.

\section{Results and discussion}

\subsection{Effects of $N$ doses on growth and yield}

The application of nitrogen exerted a significant $(p=$ $0.05)$ positive influence on the growth and yield attri- 
butes, and yield of wheat compared to its omission. As given in Table 1, the omission of $\mathrm{N}$ reduced the plant height, number of spikes per square meter, spike length and number of spikelets per spike. The nitrogen rates greater than $100 \mathrm{~kg} \mathrm{ha}^{-1}$ exerted a positive, but insignificant, influence on these attributes of the crop, stating that the efficacy of $\mathrm{N}$ decreased as its dose ex- ceeded $100 \mathrm{~kg} \mathrm{ha}^{-1}$. The spike length and the number of spikelets per spike increased with the increasing $\mathrm{N}$ rate up to this level, above which the trend of variation in these attributes of the crop reversed, implying that a higher than $100 \mathrm{~kg} \mathrm{ha}^{-1} \mathrm{~N}$ dose suppressed the development of the spikes. The 1000-grain weight of wheat decreased gradually as the $\mathrm{N}$ dose increased.

Table 1. The growth and yield attributes, and yield of wheat under irrigation by municipal wastewater and different nitrogen levels.

\begin{tabular}{|c|c|c|c|c|c|c|c|c|c|}
\hline Treatment & $\begin{array}{c}\text { Plant } \\
\text { height } \\
(\mathrm{cm})\end{array}$ & $\begin{array}{c}\text { Max leaf } \\
\text { area } \\
\text { index }\end{array}$ & $\begin{array}{c}\text { Spikes } \\
\text { m }^{-2} \\
(\text { no. })\end{array}$ & $\begin{array}{c}\text { Spike } \\
\text { length } \\
(\mathrm{cm})\end{array}$ & $\begin{array}{c}\text { Spikelets } \\
\text { spike }^{-1} \\
\left(\mathbf{N}^{0}\right)\end{array}$ & $\begin{array}{c}\text { 1000- } \\
\text { grain } \\
\text { wt. (g) }\end{array}$ & $\begin{array}{c}\text { Grain } \\
\text { yield } \\
\left(\mathrm{t} \mathrm{ha}^{-1}\right)\end{array}$ & $\begin{array}{c}\text { Biomass } \\
\text { yield } \\
\left(\mathrm{t} \mathrm{ha}^{-1}\right)\end{array}$ & $\begin{array}{c}\text { Harvest } \\
\text { index }\end{array}$ \\
\hline $\mathbf{N}_{0}$ & $87.9^{\mathrm{a}}$ & $1.68^{\mathrm{a}}$ & $262.7^{\mathrm{a}}$ & $6.56^{\mathrm{a}}$ & $10.33^{\mathrm{a}}$ & $46.66^{\mathrm{a}}$ & $1.02^{\mathrm{a}}$ & $3.43^{\mathrm{a}}$ & $0.300^{\mathrm{a}}$ \\
\hline $\mathbf{N}_{1}$ & $98.6^{\mathrm{bc}}$ & $3.00^{\mathrm{b}}$ & $344.7^{\mathrm{b}}$ & $9.51^{\mathrm{b}}$ & $16.10^{\mathrm{b}}$ & $44.25^{\mathrm{ab}}$ & $3.90^{\mathrm{b}}$ & $10.91^{\mathrm{b}}$ & $0.357^{\mathrm{ab}}$ \\
\hline $\mathbf{N}_{2}$ & $100.9^{b}$ & $3.55^{\mathrm{b}}$ & $362.0^{\mathrm{b}}$ & $10.70^{c}$ & $17.33^{\mathrm{c}}$ & $43.65^{\mathrm{ab}}$ & $4.22^{\mathrm{b}}$ & $11.14^{\mathrm{b}}$ & $0.379^{\mathrm{b}}$ \\
\hline $\mathbf{N}_{3}$ & $98.2^{c}$ & $3.23^{\mathrm{b}}$ & $353.4^{\mathrm{b}}$ & $9.48^{\mathrm{b}}$ & $15.67^{b}$ & $43.22^{\mathrm{ab}}$ & $3.42^{\mathrm{b}}$ & $11.20^{\mathrm{b}}$ & $0.346^{\mathrm{ab}}$ \\
\hline $\mathbf{N}_{4}$ & $101.2^{\mathrm{b}}$ & $3.68^{\mathrm{b}}$ & $382.0^{\mathrm{b}}$ & $10.14^{\mathrm{bc}}$ & $16.97^{\mathrm{c}}$ & $41.42^{b}$ & $3.62^{\mathrm{b}}$ & $9.76^{c}$ & $0.325^{\mathrm{ab}}$ \\
\hline HSD $_{0.05}$ & 2.6 & 1.02 & 59.2 & 0.89 & 0.81 & 4.75 & 1.00 & 1.05 & 0.066 \\
\hline
\end{tabular}

Common letter(s) within the same column do not differ significantly at $5 \%$ level of significance analyzed by Tukey's test.

The application of $\mathrm{N}$ caused enormous increase in the biomass and grain yield of wheat; the least values of both yields were obtained in the treatment with $\mathrm{N}$ control $\left(\mathrm{N}_{0}\right)$. The biomass at maturity increased by $114 \%$ and the grain yield by $225 \%$ in $\mathrm{N}_{1}(80$ $\left.\mathrm{kg} \mathrm{N} \mathrm{ha}{ }^{-1}\right)$ over $\mathrm{N}_{0}$. The treatment $\mathrm{N}_{2}\left(100 \mathrm{~kg} \mathrm{~N} \mathrm{ha}^{-1}\right)$ produced the maximum grain yield of $4.22 \mathrm{t} \mathrm{ha}^{-1}$ and $\mathrm{N}_{3}\left(120 \mathrm{~kg} \mathrm{~N} \mathrm{ha}^{-1}\right)$ produced the maximum biomass yield of $11.19 \mathrm{t} \mathrm{ha}^{-1}$ at maturity. As depicted in Figure 1, the maximum grain and biomass yields, obtained under different treatments, provided a nonlinear relation between them (A) similar to that reported by Zhang et al. (2008). The maximum grain yield versus the maximum leaf area index also followed a non-linear relation as depicted in Figure 1 (B). It is thus exposed that the wheat crop with the maximum biomass yield or the maximum leaf area index may not necessarily produce the maximum grain yield. 


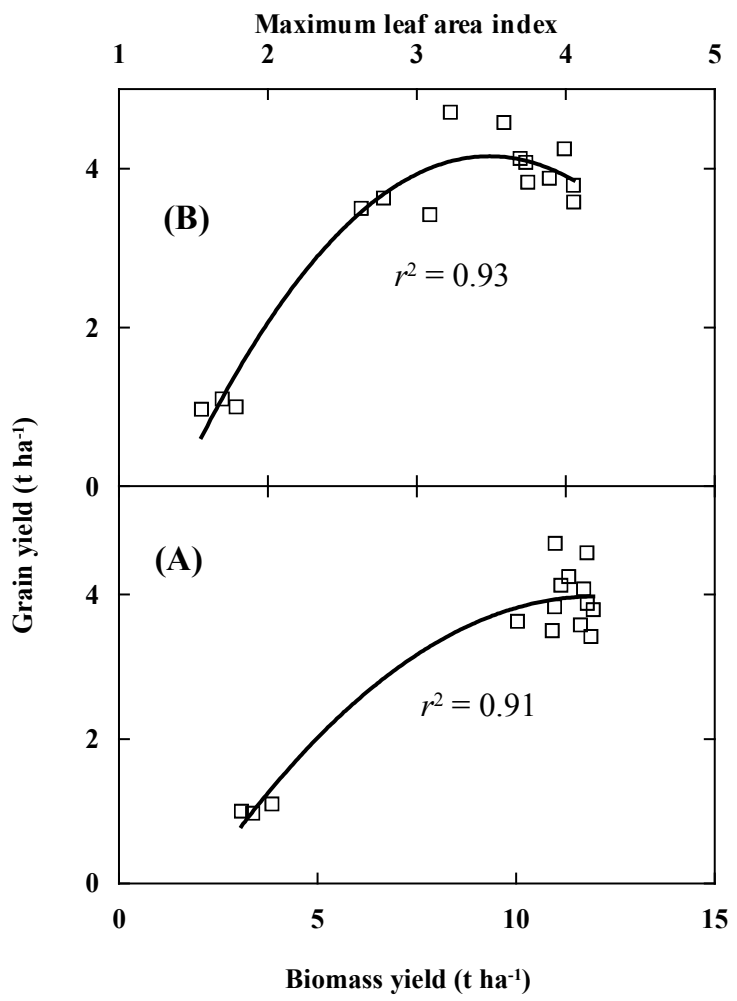

Figure 1. (A) The grain yield versus biomass and (B) grain yield versus the maximum leaf area index relationships for wheat grown under irrigation by municipal wastewater and different nitrogen $(\mathrm{N})$ levels.

\subsection{Effects of $P$ doses on growth and yield}

The omission of phosphorus $\left(\mathrm{P}_{0}\right)$ significantly reduced the growth and yield attributes of wheat except the 1000-grain weight and harvest index compared to its inclusion (Table 2). The degree of reduction of the crop attributes was however smaller than that due to the omission of nitrogen (Table 1), stating that the $\mathrm{P}$ was a lesser impact-generating nutrient than the $\mathrm{N}$ on the growth and yield attributes of wheat. The application of $\mathrm{P}$ augmented, in most cases insignificantly, all the growth and yield attributes, and yield of wheat (Table 2). The treatment $\mathrm{P}_{3}$ compri- sing $30 \mathrm{~kg} \mathrm{P} \mathrm{ha}{ }^{-1}$ produced the most superior values of the leaf area index, number of spikes per square meter, spike length, number of spikelets per spike and 1000-grain weight. The treatment $20 \mathrm{~kg} \mathrm{P} \mathrm{ha}{ }^{-1}$ provided the utmost grain yield and harvest index, while the treatment $40 \mathrm{~kg} \mathrm{Pha}^{-1}$ produced the longest plant height and the maximum biomass yield. Like nitrogen, the contribution of $\mathrm{P}$ in increasing the grain yield ceased before ceasing its positive contributions in the other attributes of wheat. Consequently, the grain yield increased, at decreasing rates, with the increasing biomass yield and the maximum leaf area index (Figure $2 \mathrm{~A}, \mathrm{~B}$ ). 
Table 2. The growth and yield attributes, and yield of wheat under irrigation by municipal wastewater and different phosphorus levels.

\begin{tabular}{|c|c|c|c|c|c|c|c|c|c|}
\hline Treatment & $\begin{array}{c}\text { Plant } \\
\text { height } \\
(\mathrm{cm})\end{array}$ & $\begin{array}{c}\text { Max leaf } \\
\text { area } \\
\text { index }\end{array}$ & $\begin{array}{c}\text { Spikes } \\
\mathbf{m}^{-2} \\
(\text { no. })\end{array}$ & $\begin{array}{l}\text { Spike } \\
\text { length } \\
(\mathrm{cm})\end{array}$ & $\begin{array}{c}\text { Spikelets } \\
\text { spike }^{-1} \\
\text { (no.) }\end{array}$ & $\begin{array}{l}\text { 1000- } \\
\text { grain } \\
\text { wt. (g) }\end{array}$ & $\begin{array}{c}\text { Grain } \\
\text { yield } \\
\left(\mathrm{t} \mathrm{ha}^{-1}\right)\end{array}$ & $\begin{array}{c}\text { Biomass } \\
\text { yield } \\
\left(\mathrm{t} \mathrm{ha}^{-1}\right)\end{array}$ & $\begin{array}{c}\text { Har- } \\
\text { vest } \\
\text { index }\end{array}$ \\
\hline$P_{0}$ & $94.9^{\mathrm{a}}$ & $2.27^{\mathrm{a}}$ & $296.7^{\mathrm{a}}$ & $9.12^{\mathrm{a}}$ & $14.24^{\mathrm{a}}$ & $41.03^{\mathrm{a}}$ & $2.82^{\mathrm{a}}$ & $7.73^{\mathrm{a}}$ & $0.364^{\mathrm{a}}$ \\
\hline$P_{1}$ & $100.0^{\mathrm{b}}$ & $3.14^{\mathrm{b}}$ & $343.7^{\mathrm{b}}$ & $9.81^{\mathrm{b}}$ & $16.07^{\mathrm{b}}$ & $40.96^{\mathrm{a}}$ & $3.51^{\mathrm{ab}}$ & $9.74^{\mathrm{b}}$ & $0.362^{\mathrm{a}}$ \\
\hline $\mathbf{P}_{2}$ & $101.7^{\mathrm{b}}$ & $3.59^{\mathrm{bcd}}$ & $361.3^{\mathrm{b}}$ & $10.16^{\mathrm{bc}}$ & $17.13^{c}$ & $40.30^{\mathrm{a}}$ & $4.16^{\mathrm{b}}$ & $10.79^{\mathrm{bc}}$ & $0.386^{\mathrm{a}}$ \\
\hline $\mathbf{P}_{3}$ & $102.5^{\mathrm{b}}$ & $3.77^{\mathrm{d}}$ & $372.7^{\mathrm{b}}$ & $10.23^{\mathrm{c}}$ & $16.90^{\mathrm{c}}$ & $41.13^{\mathrm{a}}$ & $4.09^{b}$ & $11.17^{\mathrm{c}}$ & $0.367^{\mathrm{a}}$ \\
\hline $\mathbf{P}_{4}$ & $102.8^{\mathrm{b}}$ & $3.75^{\mathrm{cd}}$ & $366.7^{\mathrm{b}}$ & $10.09^{\mathrm{bc}}$ & $16.68^{\mathrm{c}}$ & $41.13^{\mathrm{a}}$ & $3.78^{\mathrm{b}}$ & $11.25^{\mathrm{c}}$ & $0.336^{\mathrm{a}}$ \\
\hline HSD $_{0.05}$ & 3.9 & 0.45 & 41.9 & 0.36 & 0.57 & 2.98 & 0.80 & 1.16 & 0.054 \\
\hline
\end{tabular}

Common letter(s) within the same column do not differ significantly at $5 \%$ level of significance analyzed by Tukey's test.

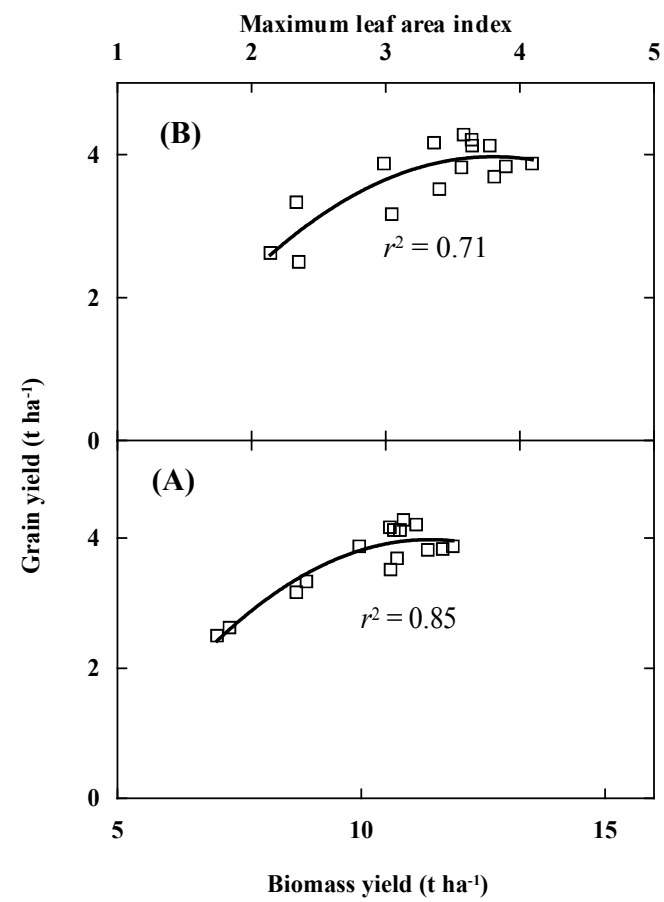

Figure 2. (A) The grain yield versus biomass and (B) grain yield versus the maximum leaf area index relationships for wheat grown under irrigation by municipal wastewater and different phosphorus (P) levels.

\subsection{Effects of $K$ doses on growth and yield}

The growth and yield attributes, and yield of wheat improved, generally, with the increasing dose of $\mathrm{K}$.
However, unlike $\mathrm{N}$ and $\mathrm{P}$, the $\mathrm{K}$ did not impart any significant positive influence on these crop attributes (Table 3). The crop attributes also did not differ significantly among the treatments consisting of different 
doses of K. Also, unlike $\mathrm{N}$ and $\mathrm{P}$, the higher doses of $\mathrm{K}$ did not reveal considerable negative impacts on the growth and yield of wheat. A linear increase in the grain yield with the increasing biomass yield, illus- trated in Figure 3 (A), revealed a proportionate contribution of the $\mathrm{K}$ to both the yields. The grain yield was however independent of the maximum leaf area index (Figure 3B).

Table 3. The growth and yield attributes, and yield of wheat under irrigation by municipal wastewater and different potassium levels.

\begin{tabular}{|c|c|c|c|c|c|c|c|c|c|}
\hline Treatment & $\begin{array}{c}\text { Plant } \\
\text { height } \\
(\mathrm{cm})\end{array}$ & $\begin{array}{c}\text { Max leaf } \\
\text { area } \\
\text { index }\end{array}$ & $\begin{array}{c}\text { Spikes } \\
\mathbf{m}^{-2} \\
(\text { no. })\end{array}$ & $\begin{array}{c}\text { Spike } \\
\text { length } \\
(\mathrm{cm})\end{array}$ & $\begin{array}{c}\text { Spikelets } \\
\text { Spike }^{-1} \\
\text { (no.) }\end{array}$ & $\begin{array}{l}\text { 1000- } \\
\text { grain } \\
\text { wt. (g) }\end{array}$ & $\begin{array}{c}\text { Grain } \\
\text { yield } \\
\left(\mathrm{t} \mathrm{ha}^{-1}\right)\end{array}$ & $\begin{array}{c}\text { Biomass } \\
\text { yield } \\
\left(\mathrm{t} \mathrm{ha}^{-1}\right)\end{array}$ & $\begin{array}{c}\text { Harvest } \\
\text { index }\end{array}$ \\
\hline $\mathbf{K}_{0}$ & $99.3^{\mathrm{a}}$ & $3.46^{\mathrm{a}}$ & $413.3^{\mathrm{a}}$ & $9.74^{\mathrm{a}}$ & $16.13^{\mathrm{a}}$ & $45.6^{\mathrm{a}}$ & $3.65^{\mathrm{a}}$ & $10.22^{\mathrm{a}}$ & $0.357^{\mathrm{a}}$ \\
\hline $\mathbf{K}_{1}$ & $100.4^{\mathrm{ab}}$ & $3.75^{\mathrm{ab}}$ & $379.3^{\mathrm{a}}$ & $9.67^{\mathrm{a}}$ & $16.73^{\mathrm{a}}$ & $42.9^{b}$ & $4.11^{\mathrm{a}}$ & $10.78^{\mathrm{ab}}$ & $0.381^{\mathrm{a}}$ \\
\hline $\mathbf{K}_{2}$ & $101.0^{\mathrm{ab}}$ & $3.75^{\mathrm{abc}}$ & $399.3^{\mathrm{a}}$ & $9.89^{\mathrm{a}}$ & $17.04^{\mathrm{a}}$ & $42.9^{b}$ & $4.00^{\mathrm{a}}$ & $10.88^{\mathrm{ab}}$ & $0.367^{\mathrm{a}}$ \\
\hline $\mathbf{K}_{3}$ & $101.5^{\mathrm{ab}}$ & $4.09^{c}$ & $410.0^{\mathrm{a}}$ & $10.11^{\mathrm{a}}$ & $17.87^{\mathrm{a}}$ & $41.3^{\mathrm{b}}$ & $3.99^{\mathrm{a}}$ & $11.29^{\mathrm{b}}$ & $0.353^{\mathrm{a}}$ \\
\hline $\mathbf{K}_{4}$ & $102.5^{\mathrm{b}}$ & $3.90^{\mathrm{bc}}$ & $415.3^{\mathrm{a}}$ & $9.67^{\mathrm{a}}$ & $16.47^{\mathrm{a}}$ & $43.3^{\mathrm{ab}}$ & $4.02^{\mathrm{a}}$ & $11.13^{\mathrm{b}}$ & $0.361^{\mathrm{a}}$ \\
\hline HSD $_{0.05}$ & 2.8 & 0.34 & 140.9 & 0.92 & 1.96 & 2.3 & 0.79 & 0.78 & 0.055 \\
\hline
\end{tabular}

Common letter(s) within the same column do not differ significantly at $5 \%$ level of significance analyzed by Tukey's test.

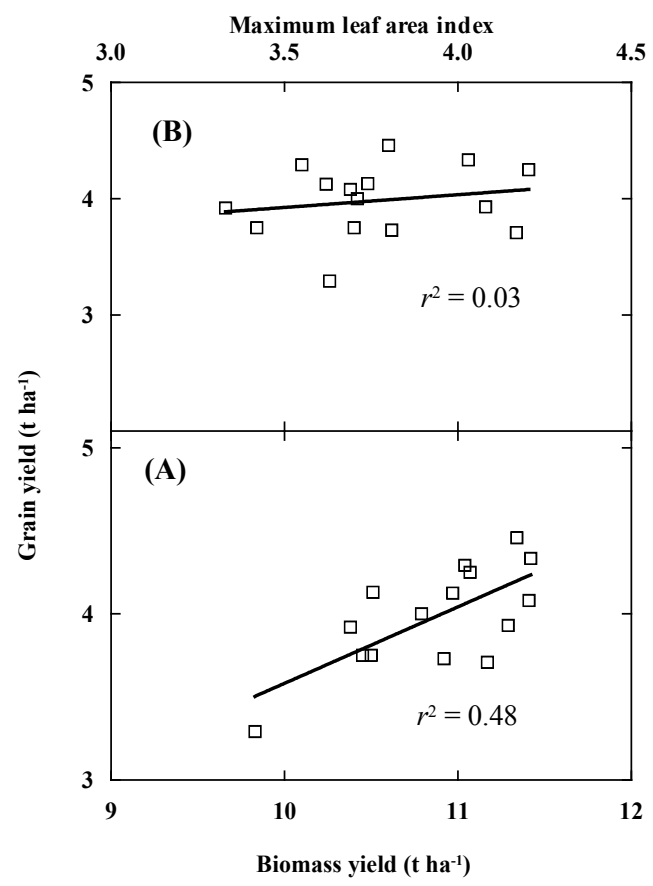

Figure 3. (A) The grain yield versus biomass and (B) grain yield versus the maximum leaf area index relationships for wheat grown under irrigation by municipal wastewater and different potassium (K) levels. 


\subsection{Nutrient use efficiency}

The nutrient use efficiencies such as - physiological efficiency, PE; agronomic efficiency, AE; and crop recovery efficiency, RE, for different treatments of the N, P and $\mathrm{K}$ are catalogued in Table 4. The PE varied from 30.7 to $35.1 \mathrm{~kg} \mathrm{~kg}^{-1}$ for $\mathrm{N}\left(\mathrm{PE}_{\mathrm{N}}\right), 159.7$ to $184.1 \mathrm{~kg} \mathrm{~kg}^{-1}$ for $\mathrm{P}\left(\mathrm{PE}_{\mathrm{P}}\right)$ and 45.0 to $48.9 \mathrm{~kg} \mathrm{~kg}^{-1}$ for $\mathrm{K}\left(\mathrm{PE}_{\mathrm{K}}\right)$. The highest $\mathrm{PE}$ was obtained at 80,10 and $60 \mathrm{~kg} \mathrm{ha}^{-1} \mathrm{~N}, \mathrm{P}$ and $\mathrm{K}$, respectively. The lower a nutrient supply, the higher was its efficiencies. The AE decreased with the increasing level of the nutrients. The N, $\mathrm{P}$ and $\mathrm{K}$ rate of 80,10 and $40 \mathrm{~kg} \mathrm{ha}^{-1}$, respectively provided the highest $\mathrm{AE}$ of $36.6,70.0$ and 11.5 $\mathrm{kg} \mathrm{kg}^{-1}$ for the corresponding nutrients. The lowest level of the nutrients provided the highest recovery efficiency except for the P, for which the RE first increased to a peak value at $20 \mathrm{~kg} \mathrm{P} \mathrm{ha}{ }^{-1}$ and then decreased with the further increase in $\mathrm{P}$ dose. The highest RE for N, P and K was 97.0, 37.5 and 10.1\%, respectively. The lowest RE, obtained for the nutrient-omission plots, was $0.30,0.06$ and $0.19 \%$, respectively. At the lower doses, the crop utilized most of the supplied nutrients. The higher doses, on the other hand, caused excessive vegetative growth of the crop that hindered the reproductive growth, and consequently, the crop failed to utilize the supplied nutrients effectively.

Table 4. The physiological efficiency (PE), agronomic efficiency (AE) and recovery efficiency (RE) of different nitrogen, phosphorus and potassium levels in cultivating wheat.

\begin{tabular}{ccccc}
\hline Treatments & $\begin{array}{c}\text { Applied nutrient } \\
\left(\mathbf{k g ~ h a} \mathbf{~}^{-\mathbf{1}}\right)\end{array}$ & $\begin{array}{c}\mathbf{P E} \\
\left(\mathbf{k g ~ h a}^{-\mathbf{1}}\right)\end{array}$ & $\begin{array}{c}\mathbf{A E} \\
\left(\mathbf{k g ~ h a}^{-\mathbf{1}}\right)\end{array}$ & $\begin{array}{c}\mathbf{R E} \\
\mathbf{( \% )}\end{array}$ \\
\hline $\mathrm{N}_{0}$ & 0 & & - & - \\
$\mathrm{N}_{1}$ & 80 & 30.72 & 36.63 & 97.00 \\
$\mathrm{~N}_{2}$ & 100 & 35.13 & 32.52 & 90.00 \\
$\mathrm{~N}_{3}$ & 120 & 34.26 & 25.18 & 77.00 \\
$\mathrm{~N}_{4}$ & 140 & 32.24 & 18.56 & 58.00 \\
\hline Phosphorus & & 31.46 & & - \\
\hline $\mathrm{P}_{0}$ & 0 & & - & 27.30 \\
$\mathrm{P}_{1}$ & 10 & 172.09 & 70.00 & 37.50 \\
$\mathrm{P}_{2}$ & 20 & 184.10 & 67.36 & 27.80 \\
$\mathrm{P}_{3}$ & 30 & 174.61 & 42.35 & 18.20 \\
$\mathrm{P}_{4}$ & 40 & 165.32 & 24.01 & - \\
\hline Potassium & & 159.72 & & 10.10 \\
\hline $\mathrm{K}_{0}$ & 0 & & - & 8.00 \\
$\mathrm{~K}_{1}$ & 40 & 45.01 & 11.47 & 8.00 \\
$\mathrm{~K}_{2}$ & 60 & 48.28 & 8.08 & 6.00 \\
$\mathrm{~K}_{3}$ & 80 & 48.92 & 4.21 &
\end{tabular}




\section{Conclusions}

The nitrogen, phosphorus and potassium doses of 100,20 and $60 \mathrm{~kg} \mathrm{ha}^{-1}$, respectively were optimum for the maximum yield of wheat under irrigation by $\mathrm{mu}-$ nicipal wastewater. Both the omission of $\mathrm{N}$ or $\mathrm{P}$ or $\mathrm{K}$ and their doses in excess of the requirement had negative effects on wheat production. At doses lower than the optimum, the crop utilized most of the supplied nutrients, while at doses higher than the optimum, the poor reproductive growth associated with the excessive vegetative growth of wheat caused ineffective utilization of the supplied nutrients. The nitrogen was the most limiting and $\mathrm{K}$ was the least limiting factors for wheat production under wastewater irrigation.

\section{Acknowledgements}

This study was carried out under the 'VLIR-Own Initiatives' program with the Bangladesh Agricultural University at Mymensingh. The authors gratefully acknowledge the funding support of the Belgian Directorate General for Development Cooperation (DGDC) through the 'Vlaamse Interuniversitaire Raad' (VLIR; Flemish Interuniversity Council).

\section{References}

Al-Salem, S.S. 1996. Environmental considerations for wastewater reuse in agriculture. Water Science and Technology. 33, 10-11, 345-353.

Biswas, T.K., Higginson, F.R., Shannon, I. 1999. Effluent nutrient management and resource recovery in intensive rural industries for the protection of natural waters. Water Science and Technology. 40, 2, 19-27.
Daradjat, A.A., Tejasarwana, R., Danakusuma, M.T., Fagi, A.M. 1991. Three-quadrant analysis of nitrogen in the soil-rice system on two lalosol soils in West Java, Indonesia. In: Vries P de, van FWT Laar, MJ Kropff eds. Simulation and Systems Analysis for Rice Production (SARP). Pudoc, Wageningen, Netherlands, pp: 155-161.

De Mendiburu, F. 2009. Agricolae: Statistical Procedures for Agricultural Research, R package version, 1.0-7.

FAO (Food and Agriculture Organization). 1992. Wastewater treatment and use in agriculture. FAO Irrigation and Drainage Paper No. 47, pp.16-17.

Feigin, A., Ravina, I., Shalhevet, J. 1991. Irrigation with Treated Sewage Effluent: Management for Environmental Protection. Springer-Verlag, Berlin.

Hussain, G., A1-Saati, A.J. 1999. Wastewater quality and its reuse in agriculture in Saudi Arabia. Desalination. 123, 241-251.

Kijne, J.W., Parthaper, S.A., Sahrawat, M.C.S. 1998. How to manage salinity in irrigated lands: a selective review with particular reference to irrigation in developing countries. SWIM Paper 2, International Water Management Institute, Colombo: Sri Lanka.

Mojid, M.A., Wyseure, G.C.L., Biswas, S.K., Hossain, A.B.M.Z. 2010. Farmers' perceptions and knowledge in using wastewater for irrigation at twelve peri-urban areas and two sugar mill areas in Bangladesh. Agricultural Water Management. 98, 79-86.

Pescod, M.B. 1992. Wastewater treatment and use in agriculture. FAO Irrigation and Drainage Paper No. 47, FAO, Rome. 
Pollice, A., Lopez, A., Laera, G., Rubino, P., Lonigro, A. 2004. Tertiary filtered municipal wastewater as alternative water source in agriculture: a field investigation in Southern Italy. Science of the total Environment 324, 1-3, 201-210.

UNESCO. 2003. Water for People, Water for Life. United Nations/World Water Assessment Programme, UNESCO, Paris and Berghahn Books, New York.
Yadav, R.K., Goyal, B., Sharma, R.K., Dubey, S.K., Minhas, P.S. 2002. Post-irrigation impact of domestic sewage effluent on composition of soils, crops and groundwater: a case study. Environment International. 28, 6, 481-486.

Zhang, X.Y., Chen, S.Y., Sun, H.Y., Pei, D., Wang, Y. 2008. Dry matter, harvest index, grain yield and water use efficiency as affected by water supply in winter wheat. Irrigation Science. 27, 1, 1-10. 
